\title{
咽喉頭異常感に㐨忷る臨床統計的観察
}

\author{
中西理恵子・米川 紘子・太田 文彦

\section{Clinical Statistics of Foreign Body Sensation in the Throat}

\author{
Rieko Nakanishi, Hiroko Yonekawa and Fumihiko Ohta \\ (Kinki University School of Medicine)
}

\begin{abstract}
Quite frequently the otolaryngologist sees patients with foreign body sensation in the throat (FBST). However, both diagnosis and treatment for such a disease still remain as difficult procedures because FBST is often evoked by complex organic diseases and the etiology of FBST is not yet fully understood enough for proper diagnosis and treatment. Our system for treatment is a 2-step procedure. First, as a screening process, anti-inflammatory enzyme and minor tranquilizers are prescribed to each patient for diagnostic treatment. Second, on the basis of the screening, patients who required further treatment were selected. A total of 1386 patients has been treated at the department of Otolaryngology of Kinki University Hospital during the 11 years from March 1979 to February 1990. Clinical statistics are reported.
\end{abstract}

Key words: foreign body sensation, clinical statistics, CMI

\begin{abstract}
緒言
咽喉頭異常感（以下異常感と略す）を訴えて 来院する患者に接する機会は, 耳鼻咽喉科医に とってかなり頻度の高いものである.しかし， 異常感患者の診察, 治療には難涉することが多 い.これは，1．異常感患者の中には，悪性疾 患をはじめとして重篤な器質的疾患を持つもの が含まれているため，これらの疾患を見逃して はならない, 2 ，異常感の発現機序については まだ不明な点が多く，診断法や治療は確立され ていないためである。
\end{abstract}

1979年 3 月から1990年 2 月までの11年間に近 畿大学耳鼻咽喉科の咽喉頭異常感外来（以下異 常感外来と略す）を受診した患者で, 経過を観 察し得たものは1386例であった.これらの症例
について統計的観察を行ったので報告する.

異常感外来の診察システム

当院では, 咽喉頭異常感の発現機序の解明之 いら目的と, 悪性腫瘍をはじめとした重篤な器 質的疾患のスクリーニングのため, 小池ら ${ }^{1)}$ 提唱した診断的治療を行ってきた。すなわち， 初診から次回受診日までの期間に一定の投薬を 行い, その効果によってさらに検査を進めるか 否かを判断している.

異常感に対する診断システムは, 図 1 に示し たよらな診断手順フローチャート2)3) に従って いる，異常感を主訴とする患者に対し，問診表 の記入，CMI，一般全身検査を行い，それ以降 は, 異常感外来にて必要な検査を施行し原因的 治療, 診断的治療を行いながら経過観察を行う. 
図 1 に全症例1386例に批けるフローチャート の各部位に該当する例数を記入した.

\section{統計的観察}

1. 異常感患者の性別・年齡別分布

全症例1386例の男女比は，男性630例（45.4 $\%$ ，女性756例（54.6\%）であった。年㱓別分 布では，男性は40藏代にピークがあり女性は30 歳代，40歳代が多かった。10歳未満の症例はな かったが，10歳代は男性11例（11/630，1.7\%）， 女性15例（15/756，2.0\%）であった（図2）。

2 . 異常感患者の年次的推移

図 3 は, 患者数の年次的推移を示したもので ある．縦軸は各年度の総患者数に対する各年齿 の患者数の占める割合を示している.

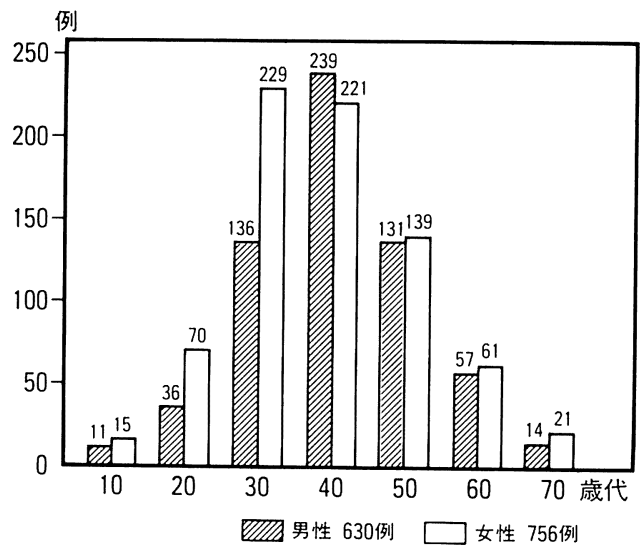

図2 性別・年路別分布

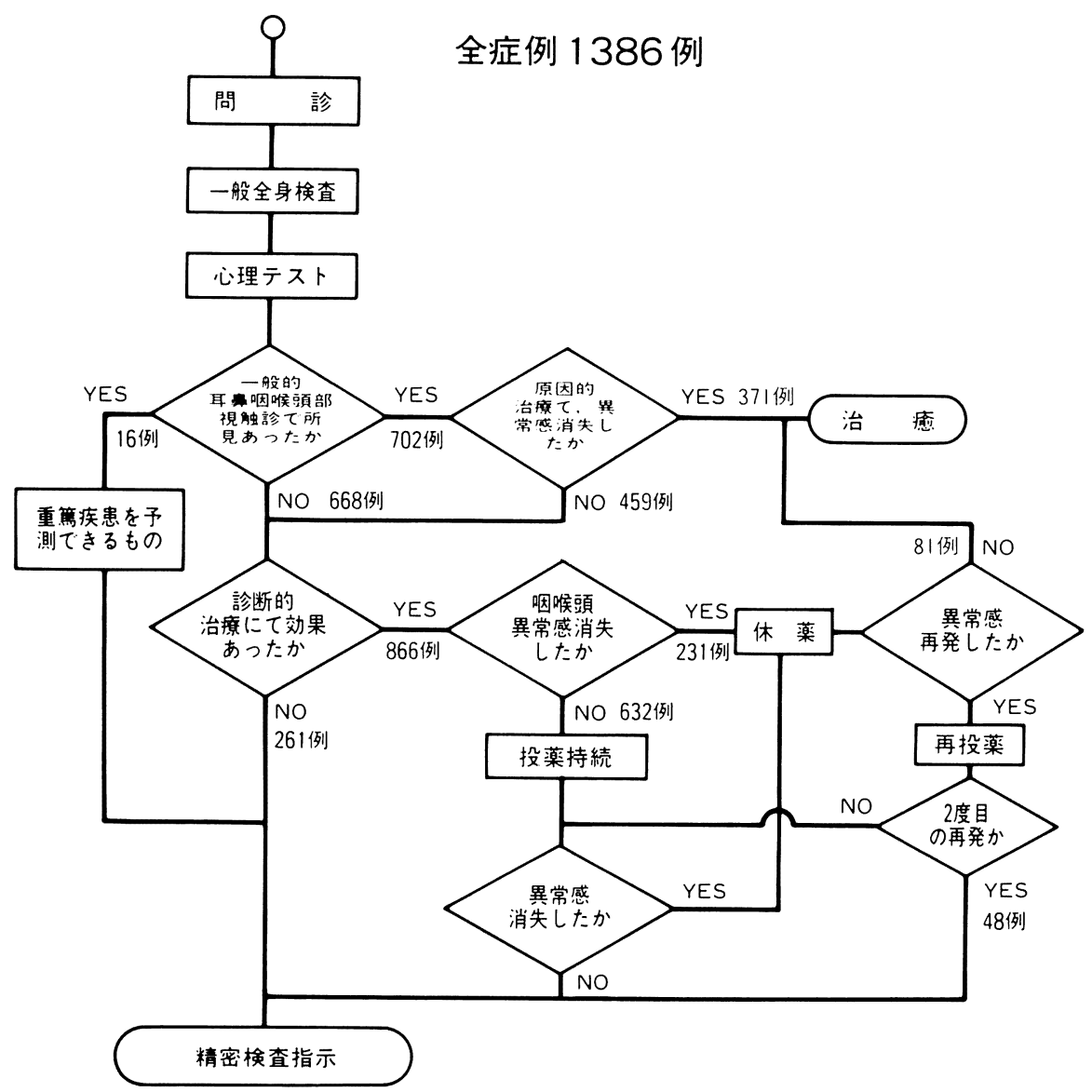

図 1 咽喉頭異常感症診断手順フローチャート 
1979年, 1984年, 1989年の各年度の患者数は, 1979年を100とすると $107 ， 141$ と増加している。

男女比の年度別推移を見ると，1:1.35〜 1： 1.52で注涪同比率であった。しかし，年齢別分 布では，10歳代，20歳代，30歳代の若年者の増 加が見られた（図 3 ）。

\section{3 . 器質的疾患}

異常感の原因であると言えるのは，その疾患 の治療を行い，治療によって異常感が消失した 場合であるが，今回，ここで用いている器質的 疾患とは，異常感の局所的原因であり得る異常 が見つかった病変を意味している。なお，診察 医は一人に限定した。

器質的疾患の認めなかったものは688例（668 /1386, 48.2\%) であり, 認めたものは718例 (718 /1386，51.8\%）であった.

器質的疾患の内訳は, 舌根扁桃肥大 181 例 (181/718，25.2\%)，慢性咽喉頭炎 - 慢性扁桃 炎177例（177/718，24.7\%)，慢性副鼻腔炎153 例 $(153 / 718,21.3 \%)$ ，鼻アレルギー49例（49 $1718 ， 6.8 \%)$ ，甲状腺疾患60例 $(60 / 718 ， 8.4$ \%)，その他98例 $(98 / 718 ， 13.6 \%$ ）であった （図 4 ）。その他の疾患98例中, 初診時には病的 所見がなく異常感症として異常感外来へ回され た症例で，検査により悪性疾患が発見されたも のは, 喉頭癌 3 例, 下咽頭癌 2 例, 食道癌 4 例, 胃癌 2 例, 甲状腺癌 5 例の計 16 例であった.

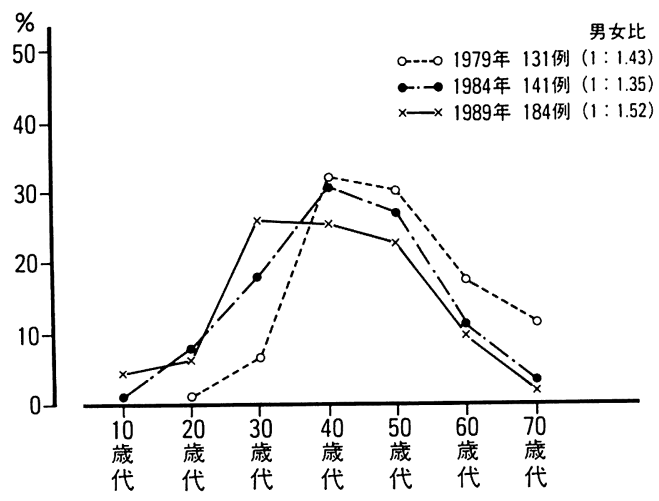

図 3 年次的推移

\section{（1）性別頻度}

各器質的疾患の男女比をみると舌根扁桃肥大 は 1：3.2 (男：女), 甲状腺疾患は 1:5.7 (男： 女）と女性が多く，咽喉頭炎は 1:0.6（男： 女), 鼻アレルギーは 1:0.6（男：女）と男性 が多い，慢性副鼻腔炎は男女差を認めなかった (図 4 ).

\section{（2）年龄別頻度}

各年齢別に器質的疾患の有無とその内訳をみ ると，40歳代と50歳代では, 器質的疾患「有り」 が各々 262例 $(262 / 460 ， 57.1 \%) ， 197$ 例（197/ 276, 71.4\%）と器質的疾患「無し」より多く, 30歳台では「有り」が181例 (181/365，49.8\%)， 「無し」が184例（184/365，50.2\%）とほぼ同 率であり，10歳代，20歳代，60歳代，70歳代で は器質的疾患を認めないものの方が多かった (図 $5-\mathrm{a}$ ).

疾患別では，30歳から50歳台の各年台におい て舌扁桃肥大, 咽喉頭炎, 慢性副鼻腔炎が注ぼ 同比率で多かった（図 5-b).

\section{4. 問診表の訴之内容}

\section{（1）質問表第 1 項}

異常感患者の訴えは，主観的訴えが中心にな っているため，まず訴えの内容を正確に捉える ことが必要である．異常感外来で用いている問 診表では, 異常感の表現をなるべく患者の感じ 方に近い答えを導くため，具体的な記述を用い

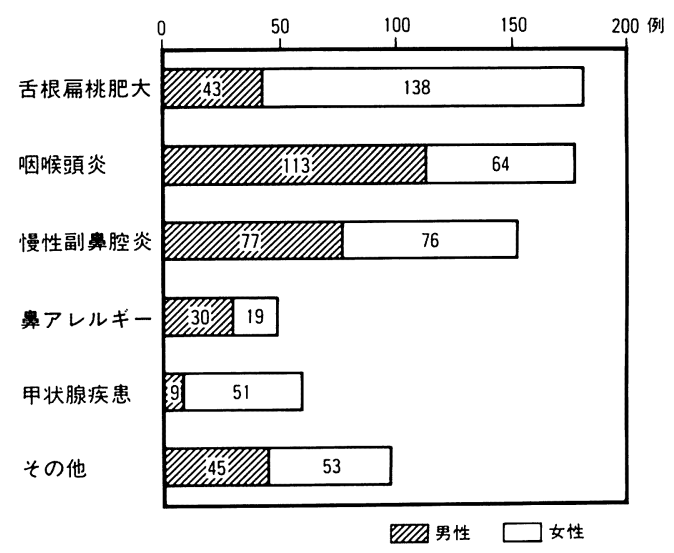

図 4 器質的疾患一性別頻度一 
た（表 1 ）。前述の器質的疾患の有無による問 診表での訴え方の差異について検討した.

(6)の「のどの奥を圧迫する感じ」と，(7)の「の どの奥のくすぐったい感じ」は，危険率 $5 \%$ 以 下で, (9の「のどの奥のやけつくょうな感じ」

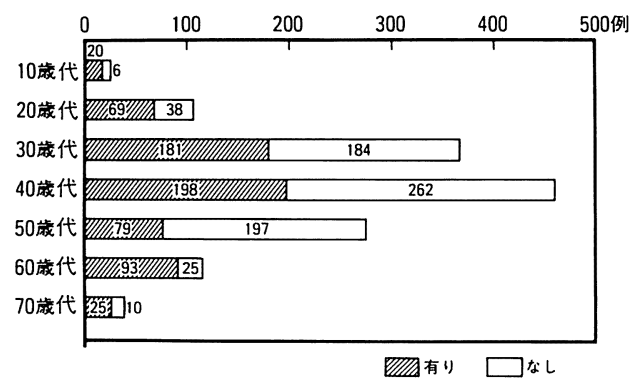

a 器質的疾患の有無

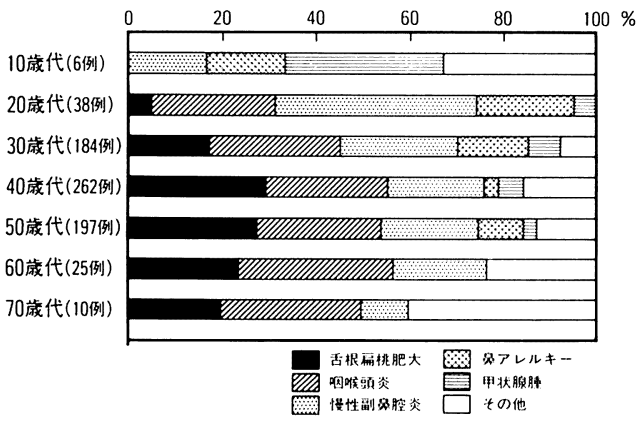

b 器質的疾患

図 5 年秢別頻度
は，危険率 $10 \%$ 以下で，器質的疾患のある症例 に有意に多かった（80の「ザラザラした感じ」 は，危険率 $10 \%$ 以下で器質的疾患のない症例に 多かった。他の訴劣 (1)〜 (4), (10)〜 (14)では, 器質 的疾患の有無による差は認めなかった。

疾患別では，咽喉頭炎では，(6)(7)の訴えが， 鼻アレルギーでは，(7)(9)の訴党が有意に多かっ た（表 2).

(2) 質問表第 2 項

第 2 項では，丁寧にみていくと，次に行らべ き検査がある程度浮かび上がってくるように設 問を選んだ（表 3 ）。突発性難聴，顔面神経麻 瘏，耳疾患患者などで，鼻・咽喉頭，頸部に病 的所見を認めないもの116名を対照群として異 常感患者との比較を行った。

項目の(1)から(3)は, いつ, 異常感を感じるか と言う質問であるが，器質的疾患の有無によら ず，つばのから飲み込みをするときに感じるも のが，616例 $(616 / 1386 ， 44.4 \%)$ を占めた. 対照群でも唾液嚥下時には，ひっかかり感を持 っているものが 9 例 $(9 / 116 ， 7.6 \%)$ あった。 しかしこの7.6\%は，ひっかかり感を特に病的 異常とは考えておらず気にしていなかった。

異常感患者において，拱食時にひっかかる感 じは213例（213/1386，15.3\%）であり，痛み は46例（46/1386，3.3\%）にあった．異常感患

表 1 咽喉頭異常感問診表（第 1 項）

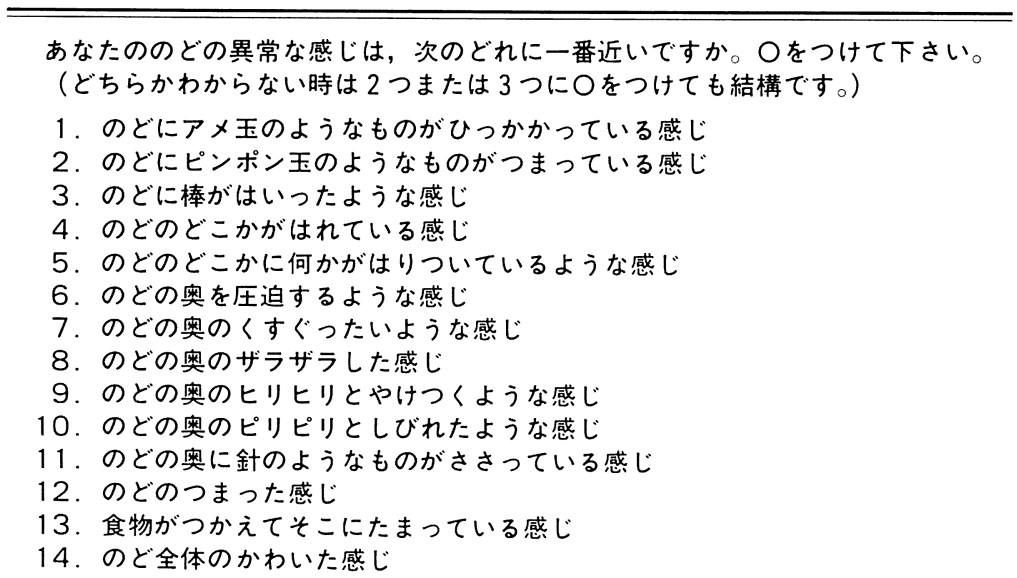


者のらち飲水時に異常感を感じるのは, 器質的 疾患を認めないものが130例（130/668，19.5\%) と器質的疾患を認めるものに比べ有意に多かっ た.

太田 ${ }^{4)}$ は口腔・咽喉頭の検査で，あまり過敏 でないのに碩固に異常感を訴える例は要注意で あると報告していることより，のどの過敏性を 知るために(5)から(9)の質問項目を設置した。対 照群と比較をすると(5)の「呼吸がしにくいと思 ったことがある」といら項目だけが対象群に比 べ異常感患者に有意に多かった（表 4 ）.

5 . 異常感の部位

異常感の感じる部位を表 5 のように 7 力所に 分け患者自身に指で示させた，器質的疾患の有 無にかかわらず正中部付近に訴えたものは，
810 例 $(810 / 1386,58.5 \%)$ であった。器質的 疾患のあるものでは，234例（234/718，32.7\%） が片側であり, 器質的疾患のない症例でも片側 にのみ異常感を感じる場合が180例（180/668， 27.0\%）であった．部位が指定できなかったり， 日により変動するものが44例 $(44 / 1386,3.17$ \%)あった（表 5 ）。

異常感の原因となり得る器質的疾患の中で比 較的, 病変の部位が明確である甲状腺疾患につ いて, 病変の部位と異常感の部位との関連につ いて検討した。

甲状腺疾患60例のらち, びまん性腫大（慢性 甲状腺炎，単純性甲状腺腫，バセドウ病）は41 例 $(41 / 60 ， 68.3 \%$ ) であり, 腫瘤（甲状腺腫 瘍，甲状腺結節）は19例（19/60，31.7\%）で

表 2 器質的疾患別問診表（第 1 項）

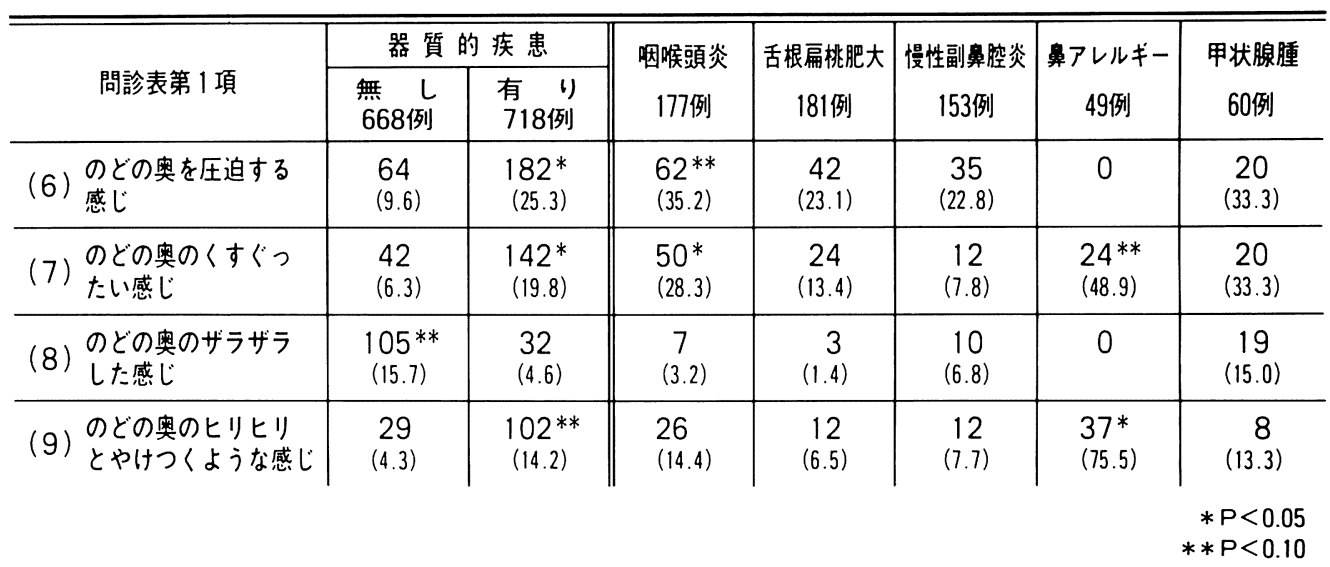

（）内は各疾患群における「はい」と答えた症例の\%を示す

表 3 咽喉頭異常感問診表（第 2 項）

1. 食物をのみこむ時にどこかにひっかかる感じがしますか（はい,いいえ）

2. 水をのむ時にひっかかる感じがしますか (はい, いいえ)

3.つばをからのみする時にひっかかるような感じがしますか（はい,いいえ)

4. 食物をのみこむ時にチクッと痛みがありますか（はい, いいえ）

5. 呼吸がしにくいと思った時がありますか（はい，いいえ）

6.あなたはのどの診察をされるのはにがてですか（はい，いいえ）

7.あなたはひと息で 5 秒以上続けてうがいができますか（はい，いいえ）

8.歯をみがく時にすぐにはき気がしますか（はい，いいえ）

9.あなたは泳げますか（はい,いいえ） 
表 4 器質的疾患別問診表（第 2 項）

\begin{tabular}{|c|c|c|c|c|}
\hline \multirow{3}{*}{ 問診表第2項 } & \multirow{3}{*}{$\begin{array}{l}\text { 対照群 } \\
116 \text { 例 }\end{array}$} & \multirow{3}{*}{$\begin{array}{l}\text { 異常感患者 } \\
\text { 1386例 }\end{array}$} & \multirow{2}{*}{\multicolumn{2}{|c|}{$\begin{array}{l}\text { 異常感患者 } \\
\text { 器質的疾患 }\end{array}$}} \\
\hline & & & & \\
\hline & & & $\begin{array}{l}\text { 無 L } \\
6688 \text { 例 }\end{array}$ & $\begin{array}{l}\text { 㤫 } \\
718 \text { 例 }\end{array}$ \\
\hline 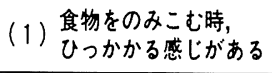 & 0 & $\begin{array}{l}213 \\
(15.3)\end{array}$ & $\begin{array}{l}127 \\
(19.0)\end{array}$ & $\begin{array}{r}86 \\
(12.0)\end{array}$ \\
\hline $\begin{array}{l}\text { （2）水をのむ時, } \\
\text { ひっかかる感しがする }\end{array}$ & 0 & $\begin{array}{l}187 \\
(13.4)\end{array}$ & $\begin{array}{l}130^{*} \\
(19.5)\end{array}$ & $\begin{array}{r}57 \\
(7.9)\end{array}$ \\
\hline 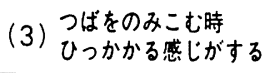 & $\begin{array}{c}9 \\
(7.6)\end{array}$ & $\begin{array}{l}616 \\
(44.4)\end{array}$ & $\begin{array}{l}287 \\
(42.9)\end{array}$ & $\begin{array}{l}329 \\
(45.8)\end{array}$ \\
\hline 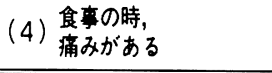 & 0 & $\begin{array}{r}46 \\
(3.3)\end{array}$ & $\begin{array}{r}26 \\
(3.9)\end{array}$ & $\begin{array}{r}20 \\
(2.8)\end{array}$ \\
\hline $\begin{array}{l}\text { （5）呼吸をしにくいと } \\
\text { 思ったここがある }\end{array}$ & $\begin{array}{c}3 \\
(2.6)\end{array}$ & $\begin{array}{l}236 * \\
(17.0)\end{array}$ & $\begin{array}{r}98 \\
(14.6)\end{array}$ & $\begin{array}{l}138 \\
(19.2)\end{array}$ \\
\hline $\begin{array}{l}\text { (6) のどの診察をされ } \\
\text { ろのは苦手た }\end{array}$ & $\begin{array}{c}53 \\
(45.7) \\
\end{array}$ & $\begin{array}{l}770 \\
(55.6)\end{array}$ & $\begin{array}{l}345 \\
(51.6)\end{array}$ & $\begin{array}{l}425 \\
(59.1)\end{array}$ \\
\hline 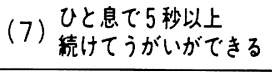 & $\begin{array}{c}48 \\
(41.4) \\
\end{array}$ & $\begin{array}{l}888^{*} \\
(64.1)\end{array}$ & $\begin{array}{l}440 \\
(65.9)\end{array}$ & $\begin{array}{l}448 \\
(62.3)\end{array}$ \\
\hline $\begin{array}{l}\text { （8）歯をみがく時 } \\
\text { はき気がする }\end{array}$ & $\begin{array}{c}18 \\
(15.5)\end{array}$ & $\begin{array}{l}255 \\
(18.4)\end{array}$ & $\begin{array}{c}101 \\
(15.1)\end{array}$ & $\begin{array}{l}154 \\
(21.4)\end{array}$ \\
\hline (9) 泳げる & $\begin{array}{c}49 \\
(42.2)\end{array}$ & $\begin{array}{l}623 \\
(44.9)\end{array}$ & $\begin{array}{l}352 \\
(52.7)\end{array}$ & $\begin{array}{l}271 \\
(37.7)\end{array}$ \\
\hline
\end{tabular}

（）内の数字は，各群における「はい,と答えた症例の\%を示す

表 5 異常感の部位

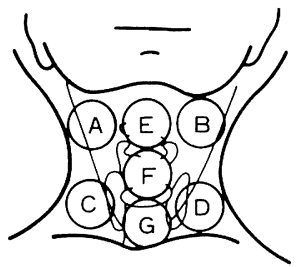

\begin{tabular}{|c|c|c|c|c|c|c|}
\hline & 位 & $\begin{array}{c}\text { 器質的疾患 } \\
(\text { 無し) }\end{array}$ & $\begin{array}{c}\text { 器質的疾患 } \\
(\text { 有り) }\end{array}$ & 咽喉頭炎 & 舌根扁桃肥大 & 慢性副鼻腔炎 \\
\hline \multirow{4}{*}{$\begin{array}{l}\text { 片 } \\
\text { 側 }\end{array}$} & A & $54(8.1)$ & $75(10.5)$ & $18(10.1)$ & $17(9.4)$ & $13(8.5)$ \\
\hline & $\mathrm{B}$ & $36(5.4)$ & $113(15.8)$ & $10(5.6)$ & $9(4.9)$ & $20(13.0)$ \\
\hline & C & $72(10.8)$ & $33(4.6)$ & $15(8.4)$ & $6(3.3)$ & $23(15.0)$ \\
\hline & $D$ & $18(2.7)$ & $14(1.9)$ & $5(2.8)$ & $7(3.9)$ & $9(5.9)$ \\
\hline \multirow{3}{*}{$\begin{array}{l}\text { 正 } \\
\text { 中 } \\
\text { 部 }\end{array}$} & $E$ & $108(16.2)$ & $37(5.2)$ & $15(8.5)$ & $47(26.0)$ & $18(11.8)$ \\
\hline & $\mathrm{F}$ & $144(21.6)$ & $182(25.3)$ & $85(48.0)$ & $20(11.4)$ & $16(10.4)$ \\
\hline & G & $180(27.0)$ & $194(27.0)$ & $21(11.9)$ & $57(31.5)$ & $61(39.9)$ \\
\hline \multicolumn{2}{|c|}{ 両側 $(A+B)$} & $48(7.2)$ & $34(4.7)$ & $12(6.7)$ & $3(1.6)$ & $1(0.6)$ \\
\hline \multicolumn{2}{|c|}{ 変動する } & $8(1.1)$ & $36(5.0)$ & $5(2.8)$ & $15(8.3)$ & $8(5.2)$ \\
\hline \multicolumn{2}{|c|}{ 計 } & $668(100 \%)$ & $718(100 \%)$ & $177(100 \%)$ & $181(100 \%)$ & $153(100 \%)$ \\
\hline
\end{tabular}


あった。びまん性腫大の症例のらち片側に異常 感を訴えたものは，6例 $(6 / 41 ， 14.6 \%)$ であ り, 腫瘤のうち正中部に異常感を訴えたものは 10 例 $(10 / 19,52.6 \%)$, 腫瘤と同側は 5 例 (5/ $19,26.3 \%)$, 反対側は 4 例 $(4 / 19,21.0 \%)$ であった。

\section{6 . 治療効果}

異常感外来では，スクリーニング治療（消炎 酵素剂十マイナートランキライザー）を4 週間 行い, 服用前後の症状の変化を患者自身の判定 により著効, 有効, やや有効, 無効の 4 段階に 分けている。他の疾患があったり，患者自身の 拒否などで投薬を行わなかった症例を不投薬群 (259例， 8.6\%) とし，スクリーニング治療に 行った症例を投薬群 (1127例，81.4\%) として 治療効果を調べた.

全症例でみると，著効は332例（332/1386， $24.0 \%$ )，有効347例 $(347 / 1386 ， 25.0 \%)$, や や有効362例 (362/1386，26.1\%)，無効345例 （345/1386，24.9\%) と各段階とも注湆同比率 であった。

治療効果の各段階における投薬群と不投薬群 を比較すると，不投薬群では101例（101/259， 39.0\%）が著効であり，28例（28/259，10.8\%) が有効，46例 (46/259，17.8\%) がやや有効， 84 例（84/259，32.4\%）が無効であった（図 6 ). 著効は不投薬群に有意に多かったが，著効例+ 有効例では両群に有意差を認めなかった．無効 例も不投薬群に有意に多かった.

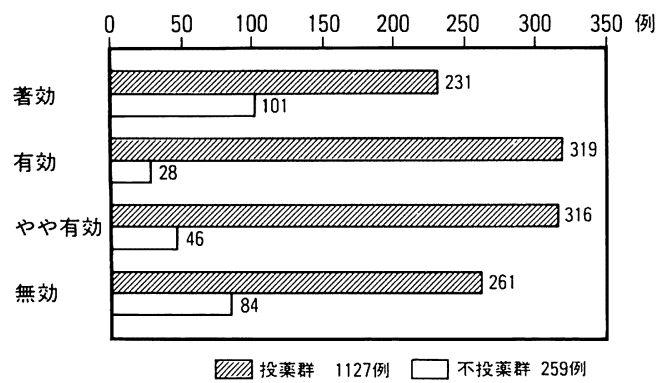

図 6 治療効果
7. CMI

異常感外来では，心因的因子を知るための簡 便な方法として CMI を用いている. 治療効果 の著効であった症例332例（332/1386，24.0\%） を治瘉群とし，無効であったもの345例（345/ 1386，24.9\%）を不変群として両者における CMI の型別判定について検討した.ささらに， 耳鼻科領域では，心因的関与が多いと考えられ ているめまい患者132例（男性58例, 女性64例, 平均年齢43.1歳）における CMI の結果と比較 した。

質問紙法は，患者が協力的でなければ信頼で きないといら久点があるため，まずその信頼性 について検討した。患者自身の記入結果と, 適 当に選び出した 10 問を直接質問した結果を比較 した。不一致は一人平均 0.43 にすぎず，CMI の記入結果は信頼性があると考兄られた。

(1) CMI の型別判定

異常感患者では, 全症例でみると I 型579例 (579/1386, 41.\%)，II型420例 $(420 / 1386,29.6$ \%)， III型294例 $(294 / 1386 ， 21.2 \%) ， \mathbb{N}$ 型85 例 $(85 / 1386 ， 6.1 \%)$ であった。 $\mathbb{V}$ 型の占める 割合をみると，めまい患者では14.7\%であり， 異常感患者では6.1\%, 治療効果別では治瘉群 は $\mathbb{N}$ 型13例（13/345，3.8\%)，不変群は $\mathbb{V}$ 型22 例 $(22 / 345 ， 6.3 \%)$ であった（図 7 ).

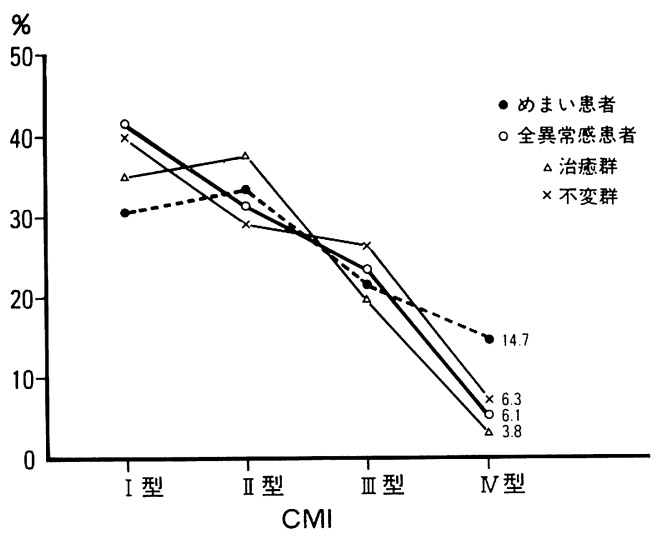

図 7 CMI 型別判定 
(2) 判別関数式

判別領域の分布傾向を詳細にみるため, 深 町5)による判別関数式に各症例の訴えの数を代 入しその值の平均值を求めた。治瘉群では男性 -0.99 ，女性 -0.81 , 不変群では男性 -0.67 , 女性ー0.61であった。 めまい患者では，男性一

表 6 判別関数式

(深町＼cjkstart建：19835) 上り改変)

\begin{tabular}{|c|c|c|c|}
\hline & 男性 & 女性 \\
\hline \multirow{2}{*}{$\begin{array}{l}\text { 異 } \\
\text { 常 } \\
\text { 感 }\end{array}$} & 治癒群 & -0.99 & -0.81 \\
\hline & 不変群 & -0.67 & -0.61 \\
\hline \multicolumn{2}{|c|}{ めまい患者 } & -0.40 & -0.19 \\
\hline \multicolumn{2}{|c|}{ 正常者 } & -0.99 & -0.69 \\
\hline \multicolumn{2}{|c|}{ 消化性潰瘍 } & -0.15 & -0.30 \\
\hline \multicolumn{2}{|c|}{ 本態性高血圧 } & -0.25 & -0.25 \\
\hline \multicolumn{2}{|c|}{ 気管支喘息 } & 0.52 & 0.37 \\
\hline \multicolumn{2}{|c|}{ 神経症 } & 0.98 & 0.68 \\
\hline
\end{tabular}

男性: $0.7566 X+0.5655 Y-3.4771=$

女性: $0.5317 X+0.6746 Y-3.3357=$

$\mathrm{X}=\sqrt{x} \quad x=\mathrm{M} \sim \mathrm{R}$

$\mathrm{Y}=\sqrt{y} \quad y=\mathrm{C}+\mathrm{I}+\mathrm{J}$
0.40，女性一0.19であった（表 6 ）.

（3）各区分別の比較

身体的自覚症については, Bの呼吸器系の訴 えだけが異常感患者に多く，他の自覚症でめま い患者の方が多かった．異常感患者に打ける治 癒群と不変群を比べると， $\mathrm{A} \sim \mathrm{L}$ の身体的項目 のすべてに拈いて不变群の方が訴えが多かった。 特に $\mathrm{D}$ 消化器系と $\mathrm{J}$ 疾病頻度は両群間の差が大 きかった（図８）。

精神的項目については，各区分でめまい患者 と異常感治癒群は，同じパターンを示した，不 変群では,すべての区分で訴光は少なかった(図 $9)$.

\section{考察}

異常感の発現機序に関しては, 従来より諸家 によりさまざまな研究がなされている．三宅6) は，本症は単一な成因のみで説明できる疾患で はないと述べ，成因的にI．局所 II. 全身 III. 心理的の三つに分類し，これを基本と考え た、諸家のあげている成因を見ると，局所因子

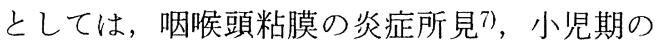
習慣性扁桃炎 899 9), 喉頭の疾患910), 過長茎状突 起 ${ }^{11)}$, 頸椎異常 ${ }^{12)}$, 舌扁桃肥大 ${ }^{13)}$, 唾液分泌低

図 8 自覚症プロフィール 1 ．身体的自覚症 
下14)，下気道アレルギー15)，甲状腺疾患9116)17) が報告されている，全身的因子としては，鉄欠

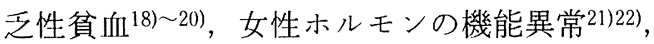
自律神経失調12) などが報告され，心理的因 子23) 25) についても様々報告されている。 し かし，報告されているこれらの成因で異常感の 病態がすべて説明されるわけではない。

さらに太田 $\left.{ }^{8}\right)$ は, 異常感を発来させる原因(原 因的要因）と異常感がなかなか消失しない要因 （遷延性要因）に分けて考光，前者は器質的变 化, それも局所の急性の変化が主であり, 後者 は心理的要因が主であろらと推察している。

この上らな多種多様な病態が複雑にからみあ って異常感が生じる，さらに，異常感を訴えて 来院する患者の中には，0.5 2.5\%の悪性疾患 が潜在する26)27) と言われていることより臨床家 にとって悪性疾患を見逃してはならないといら 責務がある.このような疾患を扱うに当たって， 小池ら日)は，スクリーニング法として診断的治 療法を提唱しており，我々もこの方法を実施し ている，悪性疾患を見逃さないために，全例に 精密検查を行らことは, 日常臨床では不可能に 近いし，患者の経済的負担も大きい，そのため， スクリーニング治療効果により精査すべき症例 を選び出すシステムを作っている3117)。その結 果をふまえて臨床統計を行った。

1. 年齢, 性別患者数

異常感患者の性別では, 以前より女性がやや
多(22228) 30) といら報告が多い. 我々の場合も, 女性がやや多かった，年齢については，30歳か ら50歳代に多い31) といわれているが，我々の 症例も, 男性は40歳代, 女性は30歳と40歳代に ピークがみられた。

年次的推移では, 患者数は 10 年間に 1.4 倍に 増加している，男女比は，10年間には一定の傾 向はなかったが，年齢分布では，10歳代，20歳 代の若年者の増加が見られた．20歳未満の異常 感の報告は少ないが, 山際は学童, 生徒の異常 感についての調査を行い，20〜 40\%に異常感を 有したと報告し，それにもかかわらず受診例が 極めて少ないのは，それを重篤な疾患としてと らえていないためと，推察している32).このこ とからも，低年層でも異常感はおこり得るし， 最近では病院を受診するようになったと考兄ら れる.患者数は, マスコミの影響をらけやすく， 岩本は下咽頭癌で池田首相が亡くなった1965年 は, 異常感患者は新患者数の $33.4 \%$ 占め, 前 年の 2 倍以上に異常感の新患数が増加したと報 告している33).

\section{2 . 器質的疾患}

これまで報告された異常感の原因は, 病態追 求の立場によりそれぞれ異なり諸説があるが, 大きく分類すると，1. 炎症 2 . 増殖打よび 肥大 3 . 腫瘍 4 . 形態異常 5 . その他 になる，我々の症例は，この分類によると炎症 が 330 例 $(23.8 \%)$, 増殖および肥大 183 例

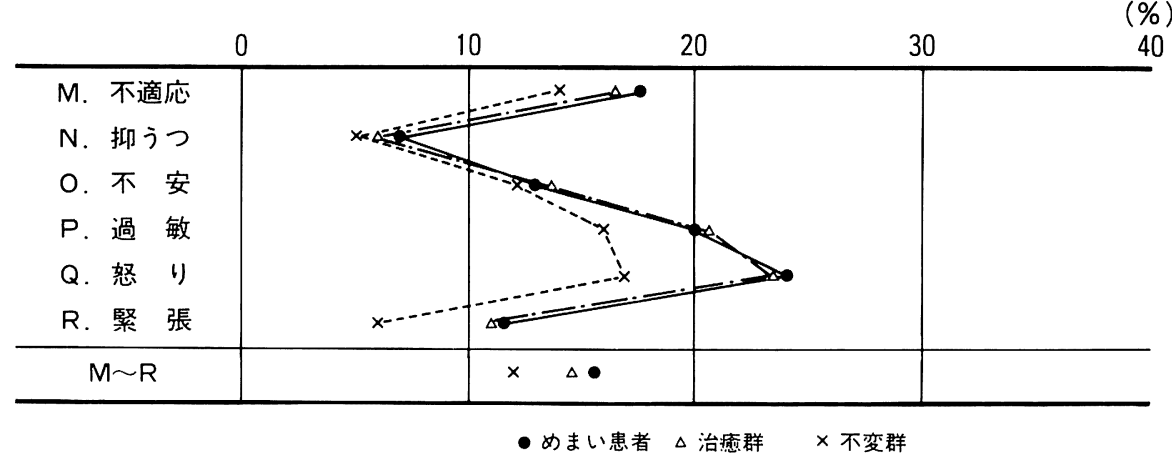

図 9 自覚症プロフィール 2. 精神的自覚症 
(13.2\%)，腫瘍 102例 (7.3\%), 形態異常24例 (1.7\%)，その他79例（5.7\%）となる.しかし， 本多34) は病理組織学的検索を行い，成人では 慢性炎症に罹患している場合が多いと, 報告し ているように舌扁桃肥大も炎症が原因であると 考觉, 鼻アレルギーも鼻閉があり口呼吸をおこ ならため咽喉頭に炎症を起こし異常感を訴える と考えると，炎症は413例で全症例の $29.8 \%$ (413/1386), 器質的疾患の 58.2\% (413/718) を占める。岩本 ${ }^{33)}$ は，異常感患者の $66.9 \%$ に 炎症所見があり，このような炎症が異常感の直 接因子と断定するわけにはいかないが誘因とし ての役割は果たしていると述べている。太田7 は, 異常感の要因には局所粘膜の炎症が何らか 関与し，特にびまん型にその傾向が強いのでは ないかと推察している.

器質的疾患の有無を年齢別に見ると, 10歳代 から20歳代の若年者では66.7\%（89/133），60 歳代から70歳代の高秢者では77.2\%（118/153） に器質的疾患を認めなかった。一方，30歳代で は器質的疾患を認めなかったものは49.8\%(181 1365)，40歳代では42.9\%（198/460)，50歳代 では28.6\%（79/276）であった．以上から若年 者や高齢者の異常感と30歳代から50歳代の異常 感とは，発現機序が異なる場合があると考えら れる。日常診察で高齿者の下咽頭梨状窩に唾液 の貯留をみることはよく経験することであるが， 高齢者の場合には器下機能の低下，局所粘膜の 知覚の低下などが関与し機能異常によって異常 感を発現させることも考えられる．若年者の場 合には，三好25）が指摘しているように心因性， 精神病性の機序が深く関与していることもあり らると思われる.

\section{3 . 異常感の訴之の内容}

診察して把握できるのは, 現在の所見である が，異常感では初診以前の経過が重要になるこ とが多く，その経過を知るためには，丁寧な問 診による他はない，しかし，異常感のように多 種多様の原因や病態が関与する訴えに対して, その全てにわたって問診することは事実上不可
能である。このため我々は問診表を作製した。 さらにこの問診表を用いることで訴え内容によ り原因がある程度予測されるかについても検討 した。“のどの圧迫する感じ”どくな゙った い感じ”は, 咽頭炎に多く, 鼻アレルギーでは, “くすぐったい感じ”と“焼け付くような感じ” が有意に多かった。 しかし, 最も訴えの多かっ た，“はれている感じ”，“何かがはりついてい る感じ”, “つまった感じ”については, 器質的 疾患の有無による差はなかった。佐藤 ${ }^{35)}$ は, 老人では症状を正確に表現できない，下咽頭癌 や声門上癌の初期では一定の部位に訴觉があり， 決して漫然とした異物感ではないと述べている。 我々の経験した悪性疾患では, 嚥下困難（実際 にものが食べられない）を訴えたものは食道癌 の 4 例中 2 例であり, 燕下痛は下咽頭癌の 2 例 のいずれもが訴えた。

以上のように訴え内容から異常感の原因を知 ることは, 困難と思われるが, 與燕下困難と與下 痛のみは, 必ず患者に直接質問し確認する必要 があると考劣らる。

4. 異常感の部位

異常感の部位については, 従来より甲状軟骨 付近に多いと言われている. 大森 ${ }^{36)}$ は，67.0 \%が甲状軟骨付近であり，一方に偏位している ものは $15.4 \%$ と述べている. 我々の結果でも器 質的疾患の有無に拘らず，正中部とくに甲状軟 骨から輪状軟骨付近に多かった。器質的疾患の ない症例でも，180例 $(180 / 668,27.0 \%)$ が片 側であった。甲状腺疾患では，び慢性腫大があ るが異常感が片側であったものは 6 例（6/41， 14.6\%), 腫瘤が一側であるにもかかわらず正 中部に異常感があったものは10例（10/19， $52.6 \%)$ ，腫瘤と反対側に異常感を訴えたもの も 4 例 $(4 / 19 ， 21.0 \%)$ あった. 三宅 ${ }^{37)}$ は，ネ クタイの結び目上り上下左右に離れている時は 局所的な病変によることが多いので注意を要す ると述べ，石塚 ${ }^{38)}$ は，顎下部付近の訴之は喉 頭蓋, 甲状軟骨上部は仮声帯, 甲状軟骨付近は 声帯と披裂部, 甲状軟骨下部は下咽頭と気管, 
食道入口部の異常を示すと報告している. しか し, 我々の結果では異常感の訴える部位と局所 的病変の部位とは必ずしも一致しない。これは, 1）及つかった器質的疾患が異常感の原因では なかった，2）佐藤35) が述べているごとく， 咽喉頭・食道は知覚の局在が不安定であること によるのではないかと推察される。

\section{5 . 治療効果}

異常感の治療としては, 原因の明らかなもの はまず，原因の除去が原則であるが，不明確な ものに対しては, 複数薬剤の服用による薬物療 法が主となるよらである. 単剤投与で治療効果 をみた報告によると, 高山 ${ }^{399}$ は, 消炎酵素剤 では $88 \%$ に効果があり，これは肉眼的に変化が みられなくとも局所の潜在性炎症が原因と推察 されるものに有効であったと述べている．精神 安定剤の単剂服用では65～80\%37)38) の高い効果 があると報告されている。しかし，木田 ${ }^{42)}$ は， 説得療法と含嗽水による治療で著効が $68.2 \%$ と よい成績であると報告している，我々の症例で も，不投薬群では101例 $(101 / 259 ， 40.0 \%)$ が 著効と, 投与群に比べ有意に多かったことから も，1）自然治瘉症例，2）診察を受け医者の 説明を聞くことで異常感が消失した症例，3） 異常感は消失しなかったが異常感が気にならな くなったり, 疾病と考えなくなった症例などが, あると考学られる. 一方, 異常感のなかには, 炎症が主なものや，心理的因子の強いものも含 まれることより, 前者に対しては消炎剂, 後者 には精神安定剂が有効と思われるので，一律に 一種類の薬剤を処方するのではなく, 症例によ り薬剤を選択して処方すべきであろう．諸検査 の結果に応じて不変例に対しては, 抗らつ風, 自律神経調節剤, 性ホルモン剂, 抗アレルギー 剤, 鉄剂, 甲状腺剂などの投与も行っているが, これらの治療にも抵抗する症例が，261例（261 /1127，20.5\%）ある.これらの治療に難渋す る症例に対しては，患者に所見や検査結果をみ せ異常感の原因は今のところ不明であるがすぐ に治療が必要な病態でなく, 今後異常感がひど
くなっていくことはないと説明する.下咽頭癌 では別な症状から始まり 6 力月経過して初めて 曣下時に異常感を訴えることもあるとの報告も あり27)，6力月は経過観察が必要であることを 納得させるようにしている。

\section{CMI}

心理テストはあくまでも心理面接の補助手段 にすぎないが，簡便でありかつ客観的定量的 データが得られる. 各質問紙法があるが神経症 のスクリーニングとしては, CMI が最も性能 がよいとされている43). 阿部法を用いれば自律 神経症の PSD 型の診断にも役立つ5). 質問紙 法を 1 種類に限定したのは, 同じ様な質問に次 々と回答を求められることによる被検者の疲労 が記入をいいかげんにする危険性を考えたため である.しかし，三好25) は CMI においては depression の診断にはほとんど役立たず， KMI（九州大学式簡易心身健康調査表）と MDI（仮面うつ病チェックリスト）の併用が有 用であると述べている.

CMI は深町3) の CMI 判定基準によると, 領 域 I は神経症であるといら仮定が $5 \%$ の有意水 準で棄却されらるので心理的に正常と診断して さしつかえなく， Nは同様に神経症と判定可能 である. 深町の内科外来心理的正常者では, 領 域 $\mathrm{N}$ は $3.0 \%$, デパートの従業員の調査では3.8 \%である. 異常感の患者に対する CMI の結果 は，木田42) は $\mathrm{N} か ゙ 15.5 \%$ ，矢野 ${ }^{44)}$ は $\mathrm{N} か ゙ 15.5$

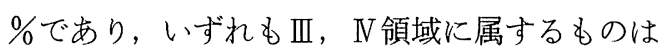
正常人に比較して多いと述べている. 我々の結 果では，めまい患者は N ガ14.7\%（19/132例） であったが，異常感患者6.1\%（85/1386例）で あり他の報告に比べ領域 $\mathrm{N}$ 型は少なかった。

治療効果別では, 治癒群の CMI の判定分布 は，ほぼ正常者と同じ分布であった．このこと を裏つける結果が, 判別関数式の值にもあらわ れている，この值は+1に近づくほど神経症と 診断される. 内科領域では, 気管支喘息, 本態 性高血圧, 消化性潰瘍が, 精神身体症とされて いるが，これらの疾患では判別関数は神経症と 
心理的正常者の中間に位置する．めまい患者も 中間に位置するが，異常感患者では特に治癒群 では，正常者に近い值を示した。太田7)は，精 神身体医学の研究の進歩により咽喉頭異常感症 が神経症とは区別すべきものと考光られ，次第 に咽喉頭神経症，食道神経症などの病名は用い られなくなったと述べているが，以上のことか ら，異常感を訴光る患者には単純に神経症が多 いと決めつけることは慎まなければならない。

しかし，諸家の報告や自験例から消炎剂のみで は異常感は不変であったが，マイナートランキ ライザーの投与により異常感が消失することも あることより心理的因子の関与の大きい症例も ある。

日常の診察に打いては，たとえ心身症あるい は神経症的訴光が強くても，患者が「のど」に こだわっている以上，まず耳鼻咽喉科的診察は 丁寧に行らべきである17).

異常感患者に対しては，患者自身に納得させ ることと，悪性疾患を決して見逃さないために 経過観察を怠らないことが大切であると考える。

\section{まとめ}

最近11年間に近畿大学付属病院耳鼻咽喉科異 常感外来を受診し, 経過を観察し得た患者 1386 例について統計的観察を行った.

1) 男女比は，1:1.2で女性に多かった。

2 ）年齢分布は, 男性は40歳代に多く，女性 は30，40歳代にピークがあり，10歳代から20歳 代の若年者の比率は，増加傾向にあった。

3 ）器質的疾患があるものは $51.8 \%$, 器質的 疾患がないものは $48.2 \%$ であった。

4 ）問診表の訴え方では，のどの奥を圧迫す る感じ，奥のくすぐったい感じ，奥のやけつく ような感じは, 器質的疾患のあるものに多かっ た。

5 ）異常感の部位は，正中部の甲状軟骨から 輪状軟骨付近に多かった。

6 ）スクリーニング治療では, 著効 $24.0 \%$, 有効 $25.0 \%$, やや有効 $26.1 \%$, 無効 $24.9 \%$ であ った。
7 ) CMI の型別では， N 型が全症例中 $6.1 \%$ であった。これを治癒別にみると，治癒群では， $\mathrm{N}$ 型は $3.8 \%$ であり，不変群は $6.3 \%$ であった。

\section{文献}

1）小池靖夫, 戸田雅克, 太田文彦 : 咽喉頭異常感 症に対する診断的治療. 耳鼻臨床 72 : 1499 1506, 1979 .

2) 太田文彦：咽喉頭異常感症の扱い方. 日耳鼻 $90: 1287 \sim 1303,1987$.

3）太田文彦：咽喉頭異常感. JOHNS 5 : 533 536, 1989.

4）太田文彦：咽喉頭異常感症. 1256 1257頁, 医 学書院, 東京, 1985 .

5) 深町 建, 金久卓也 : CMI. 三京房, 京都, 1983.

6) 三宅 弘：咽喉頭異常感症. 耳喉 46:703 709, 1974.

7）太田和博, 柏木令子, 松永 喬 : 咽喉頭粘膜の 炎症所見. 耳展 $30: 677 \sim 685,1987$.

8）太田文彦，蔦 佳明：咽頭の異常感に関する要 因一口蓋扁桃に関連して一. 口咽科 $1: 71 \sim 75$, 1989.

9）太田文彦：咽喉頭異常感症の要因. JOHNS $5:$ 1043 1048, 1989.

10）太田文彦，米川紘子：咽喉頭異常感の原因的要 因と遷延性要因一喉頭マイク口手術例での検 討一. 耳鼻臨床 補 $23: 98 \sim 103,1988$.

11）古内一郎：咽喉頭異常感症の局所的要因（過長 茎状突起)。耳展 $30: 677 \sim 685,1987$.

12）大久保仁：形態異常からみた咽喉頭異常感.耳 鼻と臨床 $28: 821 \sim 825,1982$.

13）高橋義勝：咽喉頭異常感患者のラリンゴグラム について。 日気食会報 $29: 299 \sim 310,1978$.

14）戸川 清：咽喉頭異常感と唾液分泌障害. 耳喉 $40: 209 \sim 212,1968$.

15）五十嵐博之：咽喉頭異常感症（主として自律神 経系へのアプローチ)。耳鼻臨床 $70: 1007$ 1010, 1977.

16）戸田雅克, 北野康雄, 太田文彦: 甲状腺疾患之 咽喉頭異常感.耳鼻臨床 補23：104 109, 1988.

17）太田文彦：咽頭 - 喉頭疾患. 耳鼻咽喉科 - 頭頸 部外科 MOOK No.8 耳鼻咽喉科心身症. 75 84頁, 金原出版, 1988 . 
18）三宅 弘, 松崎 久：咽喉頭異常感と不飽和鉄 結合能. 耳展 $10: 381 \sim 387,1967$.

19）柳田則之, 石田和也, 浅見清孝 : 咽喉頭異常感 （血清鉄との関連について）。耳鼻臨床 補23： $110 \sim 115,1988$.

20）田中秀夫, 藤川和成, 野末道彦: プラマー・ビ ソソン症候群の 5 例. 耳鼻臨床 補 $23: 144$ 148, 1988.

21）古田 茂, 森山一郎, 大山 勝 : 更年期障害と 咽喉頭異常感症.耳鼻臨床 補23：116 122, 1988.

22）三宅 弘：咽喉頭異常感症における卵胞，黄体, 性腺刺激ホルモン.日耳鼻 $72: 876 〜 883,1969$.

23）桂 載作：心療内科よりみた咽喉頭異常感につ いて. 耳鼻 $28: 829 \sim 833,1982$.

24）日野原正：咽喉頭異常感について（心身症の立 場加ら). 耳展 $10: 265 \sim 272,1967$.

25）三好 彰: Depression による咽喉頭異常感症 例の検討. 日耳鼻 $84: 1562 \sim 1569,1981$.

26）山浦一男, 長谷川浩通: 下咽喉頸部食道癌の診 断と治療. 耳鼻 $26: 275 \sim 284,1980$.

27）松村祐二郎：咽喉頭異常感と癌との関連につい て. 耳鼻 $24: 193 \sim 197,1978$.

28）中西泰夫 : 咽喉頭異常感症症例の自律神経機能. 日気食会報 $37: 1 \sim 7,1986$.

29）赤池徹哉, 大谷 巌, 大内 仁: 当教室に扣计 る咽喉頭異常感の統計的観察.耳鼻臨床 78 増 $1: 983 \sim 989,1985$.

30）江夏 努, 稲福 繁, 石神寛通, 他 : 咽喉頭異 常感症の検討. 耳鼻臨床 78 増 $2: 1315 \sim 1321$, 1985.

31）中西泰夫 : 咽喉頭異常感症症例の臨床統計的観 察. 日耳鼻 $90: 1606 \sim 1607,1987$.

32）山際幹和：学童・生徒を対象とした咽喉頭異常
感に関する調査成績. 日耳鼻 $90: 50 \sim 58,1987$.

33）岩本彦之丞, 大沢昌子, 新家幹子：咽・喉頭食 道異常感を訴兄る患者の扱い.耳鼻 $12: 63 \sim 66$, 1966.

34）本多芳男：舌扁桃の臨床的観察. 耳展 3:56 $59,1960$.

35）佐藤武雄 : 咽喉頭異常感症 とくに癌との鑑別. 耳展 $70: 1004 \sim 1006,1977$.

36）大森一弘：咽喉頭食道異常感症の臨床的研究. 耳展 補 $1: 1 \sim 21,1966$.

37）三宅 弘：咽喉頭異常感症・私見.耳鼻臨床 70 : 998 1000, 1977.

38）石塚洋一：咽喉頭異常感と喉頭病変との関連. 日気食会報 $33: 351 \sim 358,1982$.

39）高山乙彦：咽喉頭異常感とノイチーム．薬物療 法 2：410４12, 1969.

40）大鹿徳洋：咽喉頭異常感症に対するセレナール の使用経験. 新薬と臨床 22 : 961 964, 1978.

41）野中康弘，小川英太郎：咽喉頭異常感症に対す る Chlordiazepoxide の使用経験. 気食会報 15 ： 293 297, 1964.

42）木田亮紀，石山英一，高山乙彦：咽喉頭異常感 患者の心理テストと治療成績.耳鼻臨床 補 $23: 129 \sim 134,1988$.

43) 深町 建 : 心理テスト.内科 $47: 628 \sim 632$, 1981.

44）矢野博美, 古田 茂, 清田隆二, 他: 咽喉頭異 常感症に対する半夏厚朴湯の使用経験. 耳鼻臨 床 $75: 2075 \sim 2081,1982$.

$\left(\begin{array}{l}\text { 別刷請求先 : 中西理恵子 } \\ \text { 干589 大阪狭山市大野東377-2 } \\ \text { 近畿大学医学部耳鼻咽喉科学教室 }\end{array}\right)$ 